\title{
SOCIAL CAPITAL IN MANAGING MANGROVE ECOTOURISM AREA BY THE MUARA BAIMBAI COMMUNITY
}

\author{
Rospita O. P. Situmorang* \\ Department of Forestry, National Chung Hsing University \\ No.145, Xingda Road, South District, Taichung City 402, TAIWAN, ROC
}

Received: 16 June 2016, Revised: 4 April 2018, Accepted: 9 April 2018

\begin{abstract}
SOCIAL CAPITAL IN MANAGING MANGROVE ECOTOURISM AREA BY THE MUARA BAIMBAI COMMUNITY. The success of managing the natural environment by involving the community is strongly influenced by the local social conditions. This paper analyzes social capital inherent in the Muara Baimbai Community in Sei Nagalawan Village to manage the mangrove forest as an area valued for tourism. The study was conducted in Muara Baimbai Mangrove Area, Sei Nagalawan Village, Perbaungan District, Serdang Bedagai Regency on June until December 2014. Data were collected by observation, interview using a structured questionnaire, and in-depth interviews. The Muara Baimbai Community has strong social capital in managing the mangrove ecotourism area. An indicator of a strong social capital is a community institution which is run properly. The success of the community to rehabilitate the mangrove area in Sei Nagalawan and to utilise its resources in a sustainable manner is the result of high levels of participation of the members and the role of active cadres as symbolic power that encourage, drive, and motivate the community in their struggle. Strong motivation, fair work allocation and benefits among the members, strong internal connection, and wide external network are very important to strengthen social capital. Furthermore, the increasing welfare gained by the coastal community through increasing economic income, job opportunities, and knowledge are the benefits derived from the sustainable forest management that can maintain the existence of the community and their natural resource.
\end{abstract}

Keywords: Community, social capital, ecotourism, mangrove

MODAL SOSLAL DALAM PENGELOLAAN KAWASAN EKOWISATA MANGROVE OLEH KOMUNITAS MUARA BAIMBAI. Keberhasilan pengelolaan lingkeungan melalui pelibatan masyarakat dipengarubi oleh situasi sosial. Penelitian ini bertujuan untuk. menganalisis modal sosial yang dimiliki oleh Komunitas Muara Baimbai di Desa Sei Nagalawan dalam mengelola kawasan mangrove secara ekowisata. Penelitian ini berlokasi di kawasan mangrove Muara Baimbai, Desa Sei Nagalawan, Kecamatan Perbaungan, Kabupaten Serdang Bedagai, Sumatera Utara pada bulan Juni hingga Desember 2014. Data dikumpulkan melalui observasi lapangan, pembuatan kuesioner terstruktur, dan wawancara mendalam. Komunitas Muara Baimbai memiliki modal sosial yang tinggi dalam mengelola kawasan ekowisata mangrove. Indikator dari modal sosial yang kuat ditunjukkan dengan berjalannya institusi kelompok sesuai dengan yang diharapkan. Keberhasilan kelompok merehabilitasi kawasan mangrove di Desa Sei Nagalawan dan memanfaatkan sumberdaya tersebut secara berkelanjutan merupakan hasil dari tingkat partisipasi yang tinggi dan peran kader-kader aktif sebagai symbolic power yang mendorong dan memotivasi para anggota dalam perjuangan mereka. Motivasi yang kuat, alokasi kerja dan pembangian keuntungan yang adil, ikatan internal yang kuat, dan jaringan yang luas sangat penting dalam menguatkan modal sosial. Selanjutnya, peningkatan kesejabteraan yang didapat oleh masyarakat melalui peningkatan pendapatan, lapangan pekerjaan, dan pengetahuan adalab manfaat yang diperoleb dalam pengelolaan butan berkelanjutan yang dapat memelihara keberadaan komunitas dan sumber daya.

Kata kunci: Komunitas, modal sosial, ekowisata, mangrove

${ }^{*}$ Corresponding author: pita_80s@yahoo.com 


\section{INTRODUCTION}

Mangrove area has been degraded massively as a result of rapid development globally and nationally (Carter, Schmidt \& Hirons, 2015; Bonita \& Nizar, 2014; Rizal, Sahidin, \& Herawati, 2018). In 2010, the Indonesia mangrove area was 5,209,543.16 hectares and the area declined rapidly to $2,496,185$ hectares in 2016 (Rizal, et al., 2018). These degradations are caused by lack of proper utilization of mangrove land such as forest clearing for fish and shrimp ponds and the utilization of mangrove wood as raw material for charcoal and firewood by the community in coastal area to meet their economic needs (Carter et al., 2015; Baderan, 2017; Farley, J., Batker, D., Torre, I. \& Hudspeth, T., 2010; Setyawan, 2002). The degradation is likely to continue faster if these conditions are not controlled.

The management of mangrove forest as a protected area adjacent to the areas occupied by communities is not an easy matter. The problem is on how to strike the balance between the conservation of the mangrove forest and communities' livelihood (Ekayani, 2014; Ekayani \& Nuva, 2012). People around the forest area usually increase their income by utilizing mangrove forests, but they have limited knowledge on understanding the life cycle of wetland in mangrove ecosystem (Carter et al., 2015). Therefore, the involvement of people in the conservation management especially for sustainable rural development is an important issue. Approach models of forest management based on rural community are needed to support sustainable environment of rural communities for the next generations in the long-term (Trukhachev, 2015).

Ecotourism is one of the potential forest management for rural development, especially in fragile environments (Duangjai et al., 2014). Introduced in the 1980s, ecotourism has rapidly growth since the early 1990's between 20 and 34 percent annually (Piper \& Yeo, 2012). It has been considered as the fastest growing sub-sector of the tourism industry and as a supplementary source of economic development (Erdogan, 2017). By the high public interest on environmentally friendly products including tourism, tourism industries often use eco-label such as 'green' or 'ecofriendly' in their marketing strategy in which the World Resources Institute noted that at least 40 of 340 international eco-labels geared toward tourists and the travel industry (Piper \& Yeo, 2012). Hingham (2007) then argued that not all those responsible' forms of tourism were categorised as ecotourism but they were formed as an elaborate ruse and effective marketing tool for building further demand for tourism by clothing itself in the green mantle of mass tourism.

By the vast growth of the eco-friendly tourism terms and labels, public should be made aware that ecotourism already has a globally agreed definition and principles. The International Ecotourism Society (TIES) defines ecotourism as a responsible travel that conserves the natural environment and improves the well-being of local people (Ghosh, Siddique \& Gabbay, 2003; Kiper, 2013). Principles of ecotourism are responsible for the preservation of natural environment (Ekayani \& Nuva, 2013; Miller, 2017), beneficial to the society economically, socially and culturally by providing job opportunities, generating income, and preserving local cultures and traditions (Ekayani \& Nuva, 2013; Blaj, 2014; Miller, 2017). Lastly, ecotourism also provides environmental education to both tourists and people (Issac \& Wuleka, 2012; Kaplan, 2013; Wuleka et al., 2013). Ecotourism acts as an alternative to environmentally degrading livelihood methods, contributing to both conservation and sustainable community development (Miller, 2017)..

Community-based ecotourism is one of the models of environment management for the application of forest management or other conservation areas as tourist area (Kaplan, 2013). It is an unique type of tourism which was introduced as a way of alleviating the impact of tourism activities on the environment as well as striking balance between local people and 
the natural environment (Musavengane, 2015). The success of environmental management is achieved by involving community which will be strongly influenced the social conditions such as norms, trust, cultures, cooperation, lifestyle, and relationships among people called social capital (Nurrochmat et al., 2012; Nurrochmat et al., 2016).

Social capital is defined as a set of informal values and norms shared among members of a community group that allow the cooperation among them (Iravani \& Sharifi, 2012; Magson et al., 2014; Putnam, Leonardi \& Nanetti, 1993; Vial, 2011). From the definition, it can be seen that social capital inheres in the structure of social relationships (Portes, 2000). It concerns primarily with the values of a network which binds and bridges people with the norms of the reciprocal cooperation exchange to encourage the achievement of common goals (Jones, 2005; Nurrochmat et al., 2017). Based on this definition, there are three main elements in the social capital: i.e. trust, reciprocal and social interactions. As with Putnam et al. (1993) and Ansari (2013) argued that trust and norms of reciprocity embedded in social networks facilitate all kinds of collective action. Social capital is used for a number of productive uses. It can make easier to transfer a relevant practice from one part of an organization to another (Lesser, 2000) and in intervening public good or common resources (Lesser, 2011; Ansari, 2013).

Like physical and human capital, social capital requires maintenance. Social bonds have to be periodically renewed and reconfirmed, or else they lose efficacy (Alder \& Kwon, 2000; Lesser, 2000). It is because that social capital is sometimes rendered obsolete by contextual changes and unpredictable (Alder \& Kwon, 2000). Social capital also emphasizes on social interaction in which the actors may appropriate to use in their interests, but it should be noticed that social capital is a public good which is vulnerable to "tragedy of the commons" risks. Thus, it takes mutual commitment and cooperation from parties to build social capital. It means that no one player (actors) has exclusive ownership rights to social capital. A defection by only one party will destroy it.

Analysis of social capital is required to evaluate a social institution (Jones, 2005). Evaluation of social capital refers to the quality and quantity of social interactions horizontally which is shown by positive relationships between community members, and vertically, characterized by unequal power distribution among members and ability to cope with negative as well as positive association (Coleman, 1990). The interactions were also deeply examined in the Muara Baimbai community, a community in a coastal village in Sei Nagalawan of North Sumatera, Indonesia.

Sei Nagalawan is a coastal village which experienced significant changes on biophysical conditions in the 80 's due to the conversion of mangrove forest into large scale shrimp farmings at the eastern coastline of North Sumatera to increase shrimp production. As stated by Kustanti et al. (2014), the rapid land use change of coastal areas caused a rapid deterioration of the environment, abrasion and sea water intrusion into agricultural lands which eventually damaged the coastline. Massive deforestation of motivate environmentalists government and NGO associations to initiate rehabilitation projects of coastal areas.

The rehabilitation activities at eastern coastline of North Sumatera have been conducted since 1992, the main purpose of the activity is to carry out the rehabilitation of coastal areas by involving local communities. As a result, a lot of mangrove trees are growing along the coast and at the mouth of the rivers, including in Sei Nagalawan Village. Mangrove area is then managed independently by local community in Sei Nagalawan Village as mixed mangrove-fisheries by the establishing Nelayan Kayuh community since in 1998. In 2009, the Nelayan Kayuh community and women group joined forces to manage about 56 hectares of mangrove area as ecotourism area (Situmorang \& Barus, 2016). Furthermore, the community also integrated the management of tourist areas 
with the production of various mangrove foods for visitors and food stores. In order to promote the region and improve the coordination between interested parties, the community has built networks to the Government of Serdang Bedagai Regency, schools, universities, and NGOs (Situmorang \& Barus, 2016).

The perceived success of Muara Baimbai community in managing the ecotourism area independently is very interesting to be further researched thoroughly because the various environment management programs involving communities often fail. Failures sometimes happen because of hasty government agenda which less involvement of communities in identifying their basic needs (De Royer, Pradhan \& Juita, 2016). Chomba, Treue and Sinclair (2006) added that the program more lead to political realm. The government programs community forest program, but it is not followed by issuing a proper regulation about access to land and forest. Another reason is the fail to pay sufficient attention to the importance of smallholder business organization and related capacity-building, and to product value- chain development (FAO, 2016).

The success of involving communities commonly indicated by the existence of community's self-reliance in overcoming their social and economic problems, which according to Syahra (2003) it could be achieved if society has strong social capital in managing the organization. Therefore, the study aims to analyze the social capital owned by Muara Baimbai community in managing the mangrove ecotourism area.

\section{MATERIAL AND METHOD}

\section{A. Study Site and Time}

The research was carried out at Sei Nagalawan Village, Perbaungan District, Serdang Bedagai Regency, North Sumatera Province (Figure 1). The study was conducted from June until December 2014.

\section{B. Data Collection and Sampling Technique}

Primary data were gathered through observations, filling out questionnaire, and in-depth interview to the members of Muara Baimbai community. The Muara

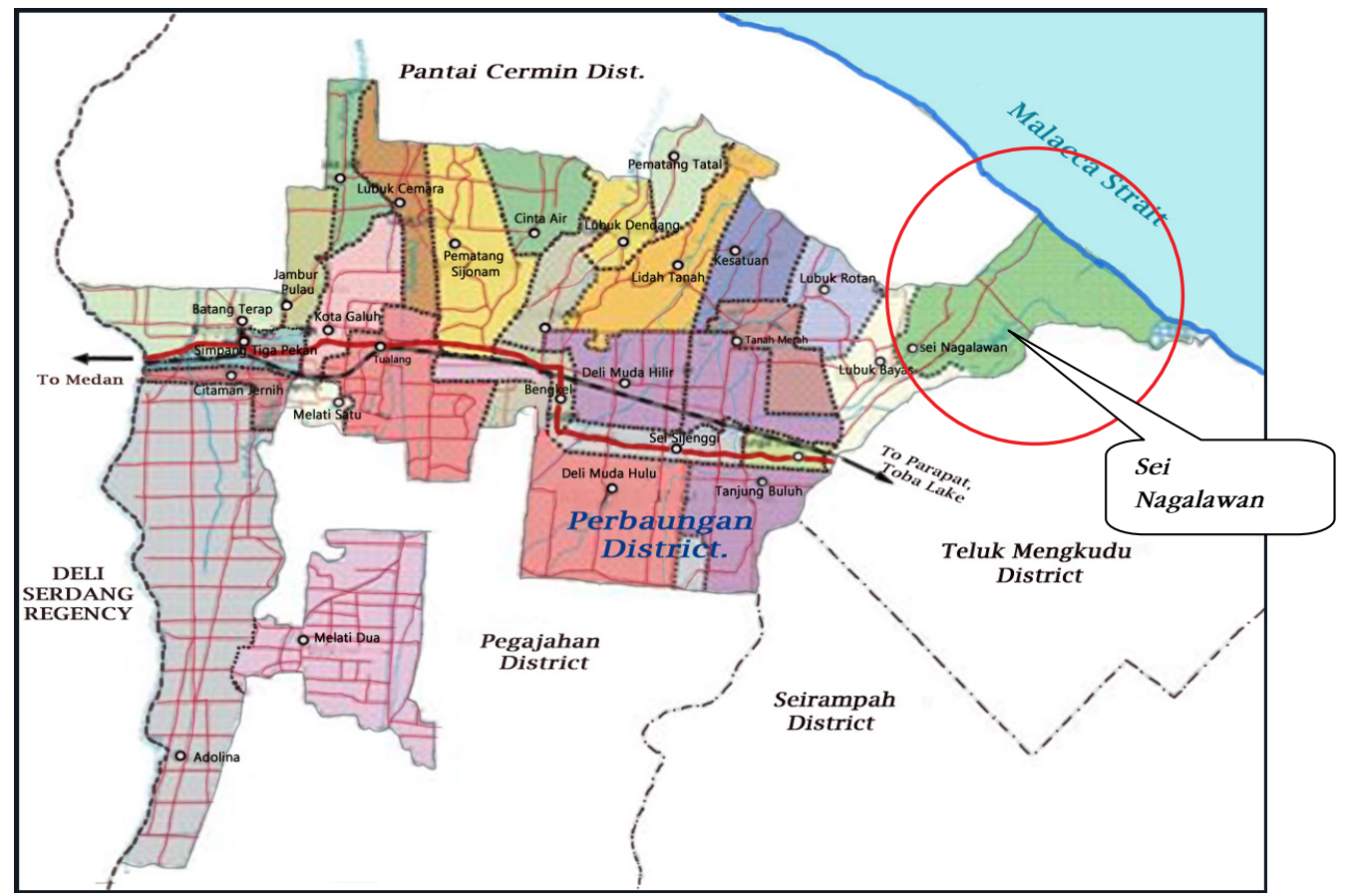

Figure 1. Perbaungan District and Sei Nagalawan Village Map

(Source: Serdang Bedagai Statistical Bureau, 2014) 
Baimbai community is joined community of fishermen and women groups who managed the mangrove area in Sei Nagalawan Village. Total number of the community member is 56 households. Twenty six respondents (head or representative of household) were randomly selected from community members to fill out the questionnaire form, and 12 respondents of managers and founders of Muara Baimbai community were interviewed to gain deeper information. The total number of respondents were 38 .

\section{Data Analysis}

The measurement of social capital and the assessment of its contribution are important to measure social capital that accurately quantifies the extent of bonding, bridging, and linking capital as individual possession (Magson et al., 2014). Van and Jan (2003) suggested that existing measurement of social capital are subjected to criticism because researchers often define terms differently, then it is difficult to develop concrete, tangible evidence of social capital that lends itself to quantitative analysis. Furthermore, Onyx and Bullen (2000) has developed a method in a study in New South Wales (Australia) to quantify the social capital criteria. The model uses many factors as the criteria of social capital such as participation at local community level, feeling of confidence and security, activities in social context, connection of neighborhood, tolerance of differences and the values of life. The criteria provided in this method are available to be adopted because they can measure the social capital in an institutional scale and its effects on the development of public participation. Based on some criterias above, the parameters used to measure the social capital in Muara Baimbai community were: level of participation; level of trust; internal and external connections (network); and values and benefits.

Data from various parameters were tabulated and interpreted using percentage table. While all the results and the information gained during the interview were interpreted and analysed descriptively by a deductive approach

\section{RESULT AND DISCUSSION}

\section{A. Level of Participation}

Faham et al. (2008) stated that level of social participation could be influenced by motivation. Motivation is shown as the willingness to take part to be a member of community when joining and running the group. By addressing the motivation of the community members of the Muara Baimbai community, the level of participation could also be determined (Table 1).

Table 1 describes that most of the community members have high level of participation on community activities. The participation consists of preparation and implementation of tour packages, placement of personnel for the tour

Table 1. Level of participants

\begin{tabular}{llrrl}
\hline \multirow{2}{*}{ No. } & \multicolumn{1}{c}{$\begin{array}{c}\text { Level of } \\
\text { participants }\end{array}$} & \multicolumn{2}{c}{$\begin{array}{c}\text { Number of } \\
\text { respondent }\end{array}$} & Description of the respondents, motivation and \\
\cline { 3 - 4 } & & \multicolumn{1}{c}{$\mathrm{n}$} & \multicolumn{1}{c}{$(\%)$} & \\
\hline 1. & Very high & 15 & 39.47 & Founder of the group, managers, and active cadres \\
2. & High & 21 & 55.26 & Management board and active members \\
3. & Moderate & 2 & 5.26 & Less active members \\
4. & Low & 0 & 0.00 & - \\
5. & Very low & 0 & 0.00 & - \\
\hline & Total & 38 & 100.00 & \\
\hline
\end{tabular}


packages and at several spots (picket, foodcourt and parking area), processing of food and snacks, participating in the strengthening of financial, repairing of facilities, as well as planting and maintenance of mangrove. Those activities are mostly done as side job, while their main jobs are fishermen and farmers. The roles, personnel placement, and work schedules are determined by the agreement of the members. Furthermore, the profit gained from each activity will be collected as a joint benefit and distributed monthly in accordance with the outpouring of the work time and the workload to get the fair share.

Sandefur \& Laumann (2000) stated that one of the characteristic of social capital is in providing benefits to the members. From the ecotourism at Sei Nagalawan, the community members are not only get economic benefit but also in social and environment benefits which can stimulate their participation and motivation to join since 1992 . It also can be interpreted that the strong motivation comes from their understanding and the benefits gained during the long involvements in conservation of mangrove through ecotourism management.

Besides influenced by the people interest on benefits, the strong participation and motivation of the community members can be seen by the people willingness to maintain the organisation (the community) to go through the structural and institutional changes since 1998. The local community firstly formed the Nelayan Kayuh Baimbai (fishermen group) community and then the Muara Tanjung Women's Group. Internal conflict had made the Nelayan Kayuh
Baimbai be dissolved. Therefore, initiated in 2006, the former members of the Nelayan Kayuh Baimbai Community consisting of fishermen merged with the Muara Tanjung Woman Group members to establish the Muara Baimbai Community by issuing the Decree of the Head of Sei Nagalawan Village No. 18.40.22/08/SK/2009 in 11th June, 2009 as well as the establishment of the community as the manager of about 56 ha mangrove area. To strengthen the community business in financial term, the merging community collected money and formed the Business Multipurpose Cooperative in 2012 namely Muara Baimbai Business Multipurpose. The cooperative also formed to complete some of needed administrative requirements when activities of community and the networks were growing.

The long journey of the Muara Baimbai community in repairing damaged mangrove forests and managing the ecotourism and its institutional arrangement shows that the group has gone through various challenges that ultimately created social independence and strong motivation in managing mangrove area and human resources. According to Bartol and Martin (1998), the right motivation is a powerful tool that reinforces behavior and triggers the tendency of continuation. The nature of willingness to participate in the group can also be seen by the main source of funding of the community which is presented in Table 2 .

Table 2 shows that operational budget of the community was mostly obtained from individual contributions (62.64\% from principal fund and $9.40 \%$ from mandatory dues). The principal

Table 2. Main source of the Muara Baimbai community funding in 2012

\begin{tabular}{llrc}
\hline No. & \multicolumn{1}{c}{ Funding categories } & Amount (IDR) & Percentage $(\%)$ \\
\hline 1. & Principal fund (IDR 200,000 x 56 members) & $11,200,000$ & 62.64 \\
2. & Mandatory dues (IDR 10,000 x 56 members) & & 9.40 \\
& $*$ October, November, December & $1,680,000$ & \\
3. & Other funds & $5,000,000$ & 27.96 \\
\hline & Total & $17,880,000$ & 100.00 \\
\hline
\end{tabular}

Source: Financial report of Muara Baimbai Community (2012) 
fund is the fund paid by the members (families) when joining the group, while mandatory dues is the monthly charges for the members. The fund are used for productive activities such as making of food, selling of food and souvenirs, and guiding services to visitors. The total revenue from the activities is shared among the members and partially set aside to the business modal.

A concept revealed by Knapp et al. (2013) described that community could participate in budgeting such as conducted by Muara Baimbai community. The participatory budgeting concept is a decision-making process which is done deliberately through negotiating among the community or citizens on distribution of public resources. Benefits gained by citizens in participatory budgeting are to increase their access to public decision-making activities, to gain access to information, and to obtain the direct relationship between participation and the quality of services provided. The explanation above confirms that the Muara Baimbai community members have the willingness to pay because they have obtained many benefits directly and indirectly from ecotourism activities. These activities also can fulfill the purpose of communities' livelihood in the area. A high participation in financial contribution donates that the community has a good capital in adherence to rules (norm) and reciprocity which will maintain the operation of the community in the future. This is in accordance with the opinion of Afify (2011) and Situmorang and Sukmana (2014) that high participation in a community is an important asset to be used for local government on sustainable management of the environment.

\section{B. Level of Trust}

$\mathrm{Yu}$ (2013) stated that trust is more important than the structural social capital. It is obvious that if actors in the network do not trust each other, no matter how dense the network is, and the high degree the actors owned, they will not be willing to share valuable information and help each other. Thus, level of trust is needed to be assessed in the community.

Table 3 shows that the level of trust between the board and members of community as well as among the members was very high (55.26\% strongly agreed). While, fairness in the distribution of jobs, satisfaction on profit sharing, and willingness to help among the members were high $(42.11 \%, 50 \%$ and $60.53 \%$ respectively agreed). It can be concluded that the community has strong trust among members and this is a good social capital in developing the community.

Trust among members, particularly of the management group, is usually strongly influenced by the acceptance of members on consistency of responsibility and cost transactions. The management of the Muara Baimbai community mostly consists of active cadres who have joined in many activities to restore mangrove areas. Bourdieu (1989) stated that the people who has power to impose

Table 3. Assessments on level of trust of Muara Baimbai community

\begin{tabular}{|c|c|c|c|c|c|c|}
\hline \multirow{2}{*}{ No. } & \multirow{2}{*}{ Descriptions } & \multicolumn{5}{|c|}{ Percentage $(\%)$} \\
\hline & & SA & A & $\mathrm{N}$ & DA & SDA \\
\hline 1. & Management of the group can be trusted & 55.26 & 36.84 & 7.89 & 0.00 & 0.00 \\
\hline 2. & $\begin{array}{l}\text { Management has treated the members fairly in } \\
\text { sharing activities }\end{array}$ & 39.47 & 42.11 & 13.16 & 5.26 & 0.00 \\
\hline 3. & $\begin{array}{l}\text { The members are satisfied in distributing profit } \\
\text { sharing based on the contribution of each } \\
\text { member } \\
\text { Members are willing to help each other }\end{array}$ & 31.58 & 50.00 & 15.79 & 2.63 & 0.00 \\
\hline 4. & Other & 23.68 & 60.53 & 2.63 & 13.16 & 0.00 \\
\hline
\end{tabular}

Notes: $\mathrm{SA}=$ Strongly agree $\mathrm{A}=$ Agree $\mathrm{N}=$ Neutral $\mathrm{DA}=$ Disagree $\mathrm{NA}=$ Strongly disagree 
upon other minds a vision, old or new, of social divisions depends on the social authority acquired in previous struggles are called as symbolic power. As happen in Sei Nagalawan, most of the members placed their trust in them because the active cadres play a role as symbolic power that have shown their responsibility to restore the damaged mangrove area and to seek many opportunities from many networks to develop their village. In terms of finance, the managers have given acceptable financial transactions and they have also given a fair profit sharing among the members. Otherwise, unfair benefit sharing and marginalization of some groups in ecotourism development and its operation could destroy trust followed by the damage of the community (Ketema, 2015). By the activities sought by the managers and the active cadres to develop the community, Avant et al. (2013) stated that this leadership style creates a culture based on openness, trust, and respect and inspires team spirit. Therefore, high social trust is required to maintain the survival of the community.

Even tough the community members generally have high level of trust to the leaders and at the sharing of activities and benefit, there are still members which are unsatisfied. Those people are mostly the less active members. The application of rules within the group about the division of activities and the benefits which is evaluated by the spending time of each member in the activity sometimes can not be accepted by the members who are less active because they get less. Level of trust to the leaders also can not be achieved perfectly because the delivery of information that sometimes can not reach all members and internal issues in the social environment that can occur. Another thing which can potentially lead to internal problems is the influence of villagers who are not members of the community. They can slowly affect members, especially members who are less active. This needs to be watched by other members or leaders to carry out the evaluation as Lesser (2000) and Alder \& Kwon (2000) argued that community needs maintenance in organization to strengthen the social capital.

\section{Internal and External Connection (Network)}

Putnam (2000) argued that the core idea of social capital is that social networks have value. Social capital is formed through the relationship between individuals and group (internal connection) (Milana \& Maldaon, 2015) which forms social structures (Baker, 1990) and between individuals and group to other actors or organisations (external connection). The internal connection of the Muara Baimbai community is presented in Table 4.

Based on Table 4, the community has a strong internal connection among the members not only socially but also economically. The

Table 4. Internal connection as a social capital

\begin{tabular}{llccccc}
\hline \multirow{2}{*}{ No. } & \multicolumn{1}{c}{ Points of assessment } & \multicolumn{5}{c}{ Percentage (\%) } \\
\cline { 3 - 7 } & \multicolumn{1}{c}{ SA } & A & N & DA & SDA \\
\hline 1. & $\begin{array}{l}\text { Greeting each other among fellow members } \\
\text { inside and outside of group meetings }\end{array}$ & 92.11 & 7.89 & 0.00 & 0.00 & 0.00 \\
2. & $\begin{array}{l}\text { Sharing many experiences within the group } \\
\text { 3. }\end{array}$ & 42.11 & 39.47 & 18.42 & 0.00 & 0.00 \\
$\quad \begin{array}{l}\text { Lending and borrowing of goods or money } \\
\text { among members }\end{array}$ & 21.05 & 55.26 & 23.68 & 0.00 & 0.00 \\
4. & $\begin{array}{l}\text { Providing economic support among } \\
\text { members for the needy families }\end{array}$ & 18.42 & 68.42 & 7.89 & 5.26 & 0.00 \\
\hline
\end{tabular}

Notes: $\mathrm{SA}=$ Strongly agree $\mathrm{A}=$ Agree $\mathrm{N}=$ Neutral $\mathrm{DA}=$ Disagree $\mathrm{NA}=$ Strongly disagree 
homogeneous social life pattern of the people in the village has made the needs and lifestyles of the villagers are not much different. The people in Sei Nagalawan are mostly fishermen and their wife as farmers and housewives. The religion and tribe dominated by Islam (religion) and Malay tribe have created the homogeneity of the society that strengthen the social interaction among members both in group activities and outside.

Relationship occurring outside of defined groups in networks is also important to improve the development of rural community. Social networks have value if there are interactions and connections in developing shared norms, trust, and reciprocity in turn foster to achieve common goals (Jones, 2005). Community members need to be involved in order to verify themselves for the validity of the new beliefs, examine consequences for themselves as an individual and to explore how they can contribute to change the effort (Belias \& Koustelios, 2014). Furthermore, Munshi (2014) stated that community networks may provide useful benefits to their members and they can give rise to inefficiencies of their own. Strong

Table 5. External interactions of the community

\begin{tabular}{|c|c|c|}
\hline $\begin{array}{l}\text { Type of } \\
\text { interactions }\end{array}$ & Type of interactions & Comments \\
\hline $\begin{array}{l}\text { Central } \\
\text { government }\end{array}$ & $\begin{array}{l}\text { Mangrove Agency sector II } \\
\text { Medan }\end{array}$ & $\begin{array}{l}\text { - The Muara Baimbai community is one of the target } \\
\text { groups in management of mangrove in the coast } \\
\text { line of North Sumatera. } \\
\text { - Many activities collaborated with the community } \\
\text { have been done in the village. }\end{array}$ \\
\hline $\begin{array}{l}\text { Local } \\
\text { government } \\
\text { (Serdang } \\
\text { Bedagai's } \\
\text { Government } \\
\text { Regency) }\end{array}$ & $\begin{array}{l}\text { 1. Department of Forestry } \\
\text { and Plantation } \\
\text { 2. Department of Tourism } \\
\text { 3. Department of Trading } \\
\text { 4. Government of Sei } \\
\text { Nagalawan Village }\end{array}$ & $\begin{array}{l}\text { - Mangrove areas managed by the community } \\
\text { became one of the ecotourism area promoted by } \\
\text { the local government in many events and occasions } \\
\text { - The government has given support in strengthening } \\
\text { the community, providing several production } \\
\text { equipments, organizing trainings and promoting } \\
\text { food products by the community. }\end{array}$ \\
\hline $\begin{array}{l}\text { Non- } \\
\text { Governmental } \\
\text { Organisation }\end{array}$ & $\begin{array}{l}\text { United Nations } \\
\text { Development Programme } \\
\text { (UNDP) Indonesia }\end{array}$ & $\begin{array}{l}\text { - Initiator in rehabilitation of mangrove area } \\
\text { including in Sei Nagalawan Village } \\
\text { - Fostering society to be environmentally active } \\
\text { cadres } \\
\text { - Facilitators of the community to manage the } \\
\text { ecotourism mangrove area } \\
\text { - Supporting financially many activities of the } \\
\text { community }\end{array}$ \\
\hline $\begin{array}{l}\text { Trading } \\
\text { institutions }\end{array}$ & $\begin{array}{l}\text { Hotels and various } \\
\text { marketing agencies in Pasar } \\
\text { Bengkel }\end{array}$ & $\begin{array}{l}\text { Marketing results of mangrove processed food } \\
\text { products produced by women's groups }\end{array}$ \\
\hline Visitors & $\begin{array}{l}\text { Groups of students } \\
\text { from various schools in } \\
\text { Serdang Bedagai Regency, } \\
\text { universities, researchers and } \\
\text { environmentalists }\end{array}$ & $\begin{array}{l}\text { Conducting excursions, studies and researches in the } \\
\text { mangrove areas }\end{array}$ \\
\hline
\end{tabular}


social ties may solve commitment problems within communities, while capable individuals outside these communities can be left out.

In addition to the importance of strengthening the internal network, a community also requires external network to expand the community. The patterned relationships connecting citizens with those outside of established groups are called social networks (Stolley, 2005). In Table 5, there are some stakeholders and institutions which have networking with the Muara Baimbai community.

Table 5 shows the interactions of the community with various stakeholders both government and non-government. This shows that the Muara Baimbai community in managing the mangrove ecotourism already has strong networks which are maintained since they have been involved in the restoration and promotion of the mangrove area as their successful job. Furthermore, after the area has been managed as tourism area by showing the beautiful scenery of the mangrove ecosystem, education on the area of tides and its ecosystem, and attractions around the area, attracts visitors and creates a new network between the parties and the community.

\section{Benefits}

Another purpose of forming groups is to get benefits both economically and socially conforming to the needs of the community. Essendi and Madise (2014) emphasized that development plans are prioritised based on communities' needs and how rural poor perceive development. Economic benefits can be obtained if such activities are done by management of certain capital for profit, while social benefits can be gained by many activities involving members. As regard the Muara Baimbai community, there are several advantages that can be obtained by activating ecotourism in the mangrove area. Table 6 indicates the benefits of ecotourism operating in the mangrove areas.

Based on Table 6, management of mangrove areas in Sei Nagalawan gives many benefits socially and economically not only for individuals but also for the group. The experiences gained by each member involved in establishing and managing the mangrove during approximately 18 years have given social benefits in increasing their knowledge in environmental and organizational management. Various activities carried out in the village have promoted the village to receive many attentions from various parties. This area has been used to be one of the pilot villages of mangrove management which is well known at the district, regional, and provincial levels. Economically, mangrove management has increased people's income either from revenue of tickets for excursions, tourist assistance, sale of food products, or other services/products. These activities also created new jobs for some members of the group. However, most of the income from the tourist areas are side income because the main income of the people is still derived from the fishing and agricultural activities.

\section{CONCLUSION}

The Muara Baimbai community has strong social capital in managing the mangrove ecotourism area. Strong social capital owned by the group is an indicator of a public institution which is run properly. The success of the community to rehabilitate the mangrove area in Sei Nagalawan and to utilise its resources in a sustainable manner is the result of high levels of participation of the members and the existence of active cadres which played a role as symbolic power on encouraging, driving, and motivating the community in their effort. Strong motivation, fair work allocation and benefits among the members, strong internal connection, and wide external network are very important to strengthen social capital. The increasing of the welfare of the Muara Baimbai communities through increasing economic income, job opportunities, and knowledge is the benefits derived from the sustainable mangrove forest management. 
Table 6. Benefits of ecotourism operating in the mangrove area

\begin{tabular}{clc}
\hline No & \multicolumn{1}{c}{ Benefits } & Percentage (\%) \\
\hline I. & Personal benefits & \\
1. & Increasing personal knowledge through training & 94.74 \\
2. & Enhancing experiences & 85.84 \\
3. & Getting jobs and permanent income & 15.79 \\
4. & Increasing of income & 81.58 \\
& Average & 69.49 \\
II. & Community's benefits & \\
1. & Self-reliance on institutional arrangements & 73.68 \\
2. & Increasing community's income by any attraction or offered tour packages & 97.37 \\
3. & Increasing technical capabilities in mangrove ecotourism & 73.68 \\
4. & Getting financial support on development of the group & 65.79 \\
5. & Enhancing network expansion & 50.00 \\
& Average & 72.11 \\
III. & Benefits to the village & \\
1. & Increasing village's income & 42.11 \\
2. & Decreasing coastal erosion & 89.47 \\
3. & Improving people's welfare & 60.53 \\
4. & Supporting in the improvement of village facilities & 21.05 \\
& Average & 53.29 \\
\hline
\end{tabular}

Remark: $\mathrm{n}=38$ respondents

\section{ACKNOWLEDGEMENT}

I would like to express my sincere gratitude to Wendra S. Manik and Emma J. Manik who patiently accompanied during the fieldworks and also to Rogerson Anokye for helping in manuscript preparation.

\section{REFERENCES}

Afify, A.M. N. (2011). Challenges and advantages of community participation as an approach for sustainable urban development in Egypt. Journal of Sustainable Development, 4(1), 23-36.

Alder, P.S. \& Kwon, S. W. (2000). Social Capital: The Good, the Bad, and the Ugly. in Knowledge and social capital: Fundation and application. Edited By Lesser E.L. (2000). Elesevier.

Ansari, S. (2013). Social capital and collective efficacy: resource and operating tools of community social control. Journal of Theoretical and Philosophical Criminology, 5(2), 75- 94.

Avant, F., Rich-Rice, K., \& Copeland, S. (2013). Leadership and rural communities. International Journal of Business, Humanities and Technology, 3(8), 53-59.

Baderan, D. W. K. (2017). Spatial distribution of damage mangrove forest area at coastal Kwandang Region, North Gorontalo District, Gorontalo Province, Indonesia (Available in Indonesia language). GeoEco. 3(1), 1-8.

Baker, W.E. (1990) Market networks and corporate behavior. American Journal of Sociology. 96(3), 589-625.

Bartol, K.M. \& Martin, D.C. (1998). Management. New York: McGraw Hil

Belias, D. \& Koustelios, A. (2014). The impact of leadership and change management strategy on organizational culture. European Scientific Journal, 10(7), 451-470. 
Blaj, R. (2014). Ecotourism and nature tourism Components of a sustainable management of forests. Journal of Horticulture, Forestry and Biotechnology, 18(4), 51- 54.

Bonita, M.K. \& Nizar, W. Y. (2004) Analysis of mangrove forest damage in the coastal area of Sekotong District of West Lombok, Indonesia. Media Bina Ilmiah. 8(1), 63-71.

Bourdieu, P. (1989). Social space and symbolic power. Sociological Theory, 7(1), 14-25.

Carter, H.N., Schmidt, S.W., \& Hirons, A.C. (2015). An international assessment of mangrove management: Incorporation in integrated coastal zone management. Diversity, 7, 74-104.

Chomba, S., Treue, T. \& Sinclair, F. (2006). The political economy of forest entitlements: can community based forest management reduce vulnerability at the forest margin? Forest Policy and Economics, 58, 37-46.

Coleman, J. (1990). Foundations of social theory. Cambridge, Mass: Harvard University Press.

Duangjai, W., Tuntates, U. \& Kroeksakul, P. (2014). The comparative evaluation of communitybased ecotourism management at mangrove forest communities in Satun Province, Thailand. International Journal of Emerging Technology and Advanced Engineering, 4(6), 42-48.

Edorgan, N. 2017. Critical views of mainstream approaches on ecotourism. Journal of Tourism and Gastronomy Studies, 5(1), 20-31.

Ekayani, M. \& Nuva. (2012). Could ex-situ conservation play effective role to bridge ecotourism and biodiversity? Case of multipurpose management of Bogor Botanic Garden, Indonesia. Proceeding of Ecotourism Research Symposium: Ecotourism for Global Peace. Seoul, Republic of Korea: Marubooks Publishing Co..

Ekayani, M. \& Nuva. (2013). Economics of ecotourism. In: Kim, Seong-il, Mihee Kang and Dian Sukmajaya (Eds.). Opportunities and Challenges of Ecotourism in ASEAN Countries. Seoul, Jungmin Publishing Co. 278pp.

Ekayani, M. (2014). Ekowisata sebagai jembatan ekologi dan ekonomi di Taman Nasional Gunung Halimun Salak. Risalah Kebijakan Pertanian dan Lingkungan, 1(1), 4-45.

Essendi, H. \& Madise, N. (2014). Factors influencing perception of development in Rural Kenya: A structural equation modeling approach. European Journal of Research in Social Sciences,
2(4), 21-36.

Faham E., Rezvanfar A. \& Shamekhi, T. (2008). Analysis of factors influencing motivation of villagers' participation in activities of social forestry: The case study of West Mazandaran. American Journal of Agricultural and Biological Sciences, 3(2), 451-456.

Farley, J., Batker, D., Torre, I. \& Hudspeth, T. (2010). Conserving mangrove ecosystems in the Philippines: Transcending disciplinary and institutional borders. Environmental Management, 45, 39-51.

FAO, (2016). Forty years of community-based forestry. Rome, Italy: Food and Agriculture Organization of the United Nations.

Ghosh, R.N., Siddique, M.A.B. and Gabbay, R. (2003), Tourism and Economic Development Case Studies from the Indian Ocean Region, Ashgate, Aldershot.

Hingham, J. (2007). Critical issues in ecotourism. Elsevier, Ltd

Iravani, M.R. \& Sharifi, S. (2012). Study of the role of social capital in assisting client of Isfahan by relying on social trust. African Journal of Business Management, 6(28), 8459-8463.

Issac, M \& Wuleka, K.C.J. (2012). Community-based ecotourism and livelihood enhancement in Sirigu, Ghana. International Journal of Humanities and Social Science, 2(18), 97-108.

Jones, S. (2005). Community-based ecotourism: The significance of social capital. Annals of Tourism Research, 32(2), 303-324.

Kaplan, S. (2013). Community based ecotourism for sustainable development in eastern black sea region an evaluation through local communities tourism perception. (Thesis). The Graduate School of Natural and Applied Sciences of Middle East Technical University, Turkey.

Ketema, T.D. (2015). Development of community based ecotourism in Wenchi Crater Lake, Ethiopia: Challenges and prospects. Journal of Hospitality and Management Tourism, 6(4), 39-46. doi: 10.5897/JHMT2014.0133.

Kiper, T. (2013). Role of ecotourism in sustainable development. In: Ozyavuz, M (Eds). Advances in Landscape Architecture. InTech Publiser.

Knapp, M., Bauer, A., Perkins, M., \& Snell, T. (2013). Building community capital in social care: Is there an economic case?. Community Development Journal, 48(2), 313-331.

Kustanti, A., Nugroho, B., Darusman, D., 
Nurrochmat, D., Krott, M., \& Schusser, C. (2014). Actor, interest and conflict in sustainable mangrove forest management - A case from Indonesia. International Journal of Marine Science, 4(6), 150-159.

Lesser, E. L. (2000). Leveraging Social Capital in Organizations. In: Lesser E.L.(Eds) Knowledge and Social Capital: Fundation and Application. Elesevier.

Magson N. R., Cravena, R.G., \& Andrews, G.H.B. (2014). Measuring social capital: The development of the social capital and cohesion scale and the associations between social capital and mental health. Australian Journal of Educational \& Developmental Psychology, 14, 202-216.

Milana, E. \& Maldaon, I. (2015). Social capital: A comprehensive overview at organizational context. Periodica Polytechnica Social and Management Sciences, 23(2), 133-141. doi: 10.3311/PPso. 7763.

Miller, C.T. (2017). Challenges and potentials of ecotourism as a form of conservation and sustainable development on Zapatera island, Nicaragua. Thesis. Sweden: Department of Urban and Rural Development, Sweden University of Agriculture Sciences, Uppsala.

Munshi, K. (2014). Community networks and the process of development. Journal of Economic Perspectives, 28(4), 49-76.

Musavengane, R. (2015). Does social capital really enhance community based ecotourism? A review of the literature. African Journal of Hospitality, Tourism and Leisure, 4(1), 1-18.

Nurrochmat, D.R., Hasan, M.F., Suharjito, D., Hadianto, A., Ekayani, M., Sudarmalik, Purwawangsa, H., Mustaghfirin, Ryandi, E.D. (2012). In: Nurrochmat \& Hasan (Eds.). Ekonomi politik kehutanan. mengurai mitos dan fakta pengelolaan hutan. (Second edition, revised version). Jakarta: INDEF.

Nurrochmat, D.R., Darusman, D.R., Ekayani, M. (2016). Kebijakan pembangunan kehutanan dan lingkungan: Teori dan implementasi. Bogor: IPB Press.

Nurrochmat, D.R., Nugroho, I.A., Hardjanto, Purwadianto, A., Maryudi, A., Erbaugh, J.T.(2017). Shifting contestation into cooperation: Strategy to incorporate different interest of actors in medicinal plants in
Meru Betiri National Park, Indonesia. Forest Policy and Economics, 83(2017), 162-168. doi:10.1016/j.forpol.2017.08.005.

Onyx, J. \& Bullen, P. (2000). Sources of social capital. In I. Winter (Eds) Social capital and public policy in Australia (Pp. 105 - 135). Melbourne: National Library of Australia.

Piper, L.A. \& Yeo, M. (2011). Ecolabels, ecocertification and ecotourism. Sustainable Tourism: Socio-Cultural, Environmental and Economics Impact, pp: 279-294

Portes, A. (2000). Social Capital: Its origins and applications in modern sociology. In: Lesser E.L.(Eds) Knowledge and social capital: Fundation and application. Elesevier

Putnam, R., Leonardi, R., \& Nanetti, R.Y. (1993). Making democracy work: Civic transition in modern Italy. NJ, USA, Princeton University Press. Princeton.

Putnam, R. (2000). Bowling alone: The collapse and revival of American community. New York: Simon and Schuster.

Rizal, A., Sahidin, A., Herawati, H. (2018) Economic Value Estimation of Mangrove Ecosystems in Indonesia. Biodiversity, 2 (1), 123-126.

Sandefur, R. L. \& Laumann, E. O. (2000) A Paradigm for Social :Capital. In: Lesser E.L.(Eds) Knowledge and Social Capital: Fundation and Application. Elesevier.

Serdang Bedagai Statistical Bureau (2014). Perbaungan district in figures 2015. Sei Rampah: Serdang Bedagai Statistical Bureau.

Setyawan, A.D. (2002). Mangrove ecosystem as a transitional area of freshwater ecosystems and marine waters ecosystems. Enviro, 2 (1), 25-40.

Situmorang, R.O.P. \& Sukmana, A. (2014). Community participation in optimization of land management in sub-watershed Arun, Samosir Regency. Inovasi, 11(3), 174-183.

Situmorang, R. O. P. \& Barus, S. (2016). Mangrove Management as source of food alternative by the women fishermen group in Sei Nagalawan, North Sumatera, Indonesia. In C.A. Siregar, Pratiwi, N. Mindawati, G. Pari, M. Turjaman, H.L. Tata ... J. Balfas (Eds). Proceeding of The International Conference of Indonesia Forestry Researchers (INAFOR) III. Research, Development, and Innovation Agency, Ministry of Environment and Forestry. 
Stolley, K. (2005). The basic of sociology. Westport, Connecticut, London: Greenwood Press.

Syahra, R. (2003). Social capital: Concepts and aplications. Jurnal Masyarakat dan Budaya, 5(1), 1-21.

Trukhachev, A. (2015). Methodology for evaluating the rural tourism potentials: A tool to ensure sustainable development of rural settlements. Sustainability, 7, 3052-3070. doi:10.3390/ su7033052.

Van Deth \& Jan, W. (2003). Measuring social capital: Orthodoxies and continuing controversies. International Journal of Social Research Methodology, 6(1), 79-92.
Wuleka, K.C.J., Ernest, B. \& Oscar, A.I. (2013). Livelihood enhancement through Ecotourism: A case of Mognori Ecovillage near Mole National Park, Damongo, Ghana. International Journal of Business and Social Science, 4(4), 129137.

Yu, C. (2013). A literature review of the effects of social capital - From the personal network perspective. International Journal of Business and Social Science, 4(12), 251-259. 